\title{
PENGARUH PEMOTONGAN TANGKAI MATA (ABLASI) TERHADAP PERTUMBUHAN JUVENIL UDANG GALAH (Macrobracbium rosenbergii)
}

\author{
Wartono Hadie ${ }^{*}$, Sri Rejeki ${ }^{* *}$ ) dan Lies Emmawati Hadie ${ }^{*}$ )
}

\begin{abstract}
ABSTRAK
Penelitian ablasi mata secara unilateral dan bilateral di laboratorium dilakukan terhadap stadium juvenil udang galah (Macrobracbium rosenbergii) dengan tujuan untuk mengetahui pengaruhnya terhadap pertumbuhan dan daya kelangsungan hidupnya.

Rancangan yang digunakan adalah Rancangan Acak Lengkap (RAL), dengan perlakuan ablasi unilateral, ablasi bilateral dan tanpa ablasi (kontrol) masing-masing 9 ulangan.

Hasil yang diperoleh menunjukkan adanya pengaruh positif dari perlakuan (ablasi) terhadap laju pertumbuhan akan tetapi tidak terhadap kelangsungan hidupnya $(P<0,05)$. Ablasi bilateral memberikan pertumbuhan paling besar 1,5 kali ablasi unilateral dan 2,5 kali dari udang tanpa ablasi. Sedangkan ablasi unilateral memberikan peningkatan pertumbuhan 1,7 kali dari udang tanpa ablasi (kontrol).
\end{abstract}

ABSTRACT: The effect of eye-stalk ablation on the growth rate and survival of giant prawn juvenile (Macrobracbium rosenbergii), by Wartono Hadie, Sri Rejeki and Lies Emmawati Hadie

Experiments on the effect of ablation to the growth and survival rate of giant prawn juveniles were conducted in the laboratory. The design used was completely randomized design (CRD) with three treatments i.e unilateral ablation, bilateral ablation and without ablation as a control, each were 9 replications.

Result of the experiment indicated that there were positive effect on the growth rates but not the survival rates. Eye-stalk ablation was increasing the growth rate but decreasing the survival rate of the prawn. Bilateral ablations of eye stalk increased the growth 1.5 times compared to unilateral ablation and 2.5 times than in control. Unilateral ablation stimulated the growth up to 1.7 times of the unablated control.

KEYWORDS: Giant prawn, eyestalk ablation

\section{PENDAHULUAN}

Pertumbuhan udang galah sangat dipengaruhi oleh kecepatan (frekuensi) ganti kulit, karena kulit yang membungkus seluruh tubuh udang tidak elastis. Kekerasan kulit tubuh udang (Arthropoda) yang terjadi setelah proses seklerotisasi dan kalsifikasi akan membatasi pertumbuhan udang dan oleh karenanya harus berganti kulit setiap proses pertumbuhannya. Kecepatan tumbuh udang galah relatif lebih lambat pada kondisi alamiahnya. Hal demikian akan menjadi kendala pada usaha budidaya baik secara ekstensif maupun secara intensif.

\footnotetext{
") Peneliti pada Instalasi Penelitian Air Tawar Pasar Minggu

*4) Dosen pada Jurusan Biologi, Fakultas MIFA, Universitas Indonesia
} 
Selain usaha-usaha pada perbaikan manajemen budidaya, teknologi ablasi juga dapat diterapkan untuk mempercepat frekuensi ganti kulit pada udang galah. Teknologi ini mampu mempercepat pertumbuhan dengan memanfaatkan kerja hormon dalam tubuh udang. Dalam tubuh udang terdapat hormon yang mempengaruhi kecepatan molting yang disebut molt accelerating hormon (MAH) (Chu \& Chow, 1992). Hormon ini berperan pada proses ganti kulit Sebaliknya ada hormon yang mempunyai cara kerja antagonistik yang justru menekan kerja hormon MAH tersebut adalah molting inhibiting hormone (MIH) (Chu \& Chow, 1992). Fungsi lain dari hormon MIH juga mempengaruhi tingkat penyerapan air pada saat sehabis ganti kulit.

Ablasi mata pada udang telah diketahui berpengaruh positif terhadap fungsi fisiologisnya, terutama terhadap peningkatan nafsu makan sehingga pertumbuhannya semakin cepat (Nurjana, 1979). Selanjutnya Mulyani (1986) melaporkan bahwa pertumbuhan tokolan udang galah yang diablasi secara unilateral jauh lebih baik dibanding dengan udang yang tidak diablasi. Udangudang yang kehilangan fungsi mata tersebut tidak mendapat kesulitan dalam memperoleh makanan, karena udang akan tertarik pada pakan melalui rangsangan aroma (Poernomo, 1985), dan bahkan udang mampu mendeteksi makanannya pada jarak $10 \mathrm{~m}$ melalui sensor saraf pada antena.

Tujuan dari penelitian ini adalah untuk melihat pengaruh ablasi yang dilakukan baik secara unilateral maupun bilateral terhadap kecepatan pertumbuhan udang.

Hipotesis : ablasi dapat meningkatkan frekuensi ganti kulit sehingga mampu meningkatkan laju pertumbuhan.

\section{BAHAN DAN METODE}

Penelitian dilaksanakan di Instalasi Penelitian Perikanan Air Tawar Pasar Minggu, dengan menggunakan 27 buah akuarium ukuran 40 x 40 x $40 \mathrm{~cm}$. yang masing-masing dilengkapi dengan aerator. Hewan uji yang digunakan adalah tokolan (juvenil) udang galah yang berasal dari Unit Pengembangan Udang Galah Pamarican dengan berat rata-rata $7,78 \mathrm{~g}$ dan panjang rata-rata $0,94 \mathrm{~cm}$ dengan kepadatan 3 ekor per akuarium. Seluruh hewan uji sebelum diperlakukan terlebih dulu diaklimatisasikan selama satu minggu.

Setelah aklimatisasi dilakukan ablasi mata udang dengan menggunakan gunting bedah steril untuk memecahkan bola mata. Bola mata dipecah (di dalam air) kemudian seluruh isi mata dikeluarkan hingga bersih (Poernomo dan Yunus, 1980). Untuk perlakuan ablasi bilateral, mula-mula ablasi dilakukan untuk mata yang sebelah dan dibiarkan selama 3 hari hingga bola mata yang pecah telah menutup, kemudian dilakukan ablasi pada mata yang sebelahnya dengan cara yang sama. Pemeliharaan dilakukan selama 8 minggu. Selama masa penelitian tersebut diberikan campuran pakan komersial dengan ubi dan siput murbai dengan perbandingan 1:1:1. Pakan diberikan 2 kali sehari pada siang 
hari dan petang hari dengan ransum 15\% bobot populasi/hari (Poernomo dan Yunus, 1980; Menasveta dan Piyatiraitivokul, 1982; Budiono et al., 1990).

Media pemeliharaan yang digunakan adalah air tawar, dengan ketinggian $26 \mathrm{~cm}$ dan disipon setiap hari. Penyiponan dimaksudkan untuk menghilangkan kotoran dan sisa pakan dalam media. Dengan demikian media tetap baik mutu airnya dan volume air tetap pada ketinggian yang sama.

Penelitian dilakukan dalam skala laboratorium dengan Rancangan Acak Lengkap 3 perlakuan dan 9 ulangan. Perlakuan yang diberikan adalah ablasi pada sebelah matanya (unilateral) dan ablasi pada kedua belah matanya (bilateral) dan tanpa ablasi sebagai kontrol.

Parameter yang diamati mencakup pertumbuhan (berat dan panjang) dan mortalitas serta kualitas air media. Pengamatan dilakukan setiap 2 pekan. Analisis data dilakukan dengan menggunakan metoda Bartlett (Gad \& Weil, 1982) dan uji Wilk \& Shapiro serta analisis varian (Steel dan Torie, 1991).

\section{HASIL DAN PEMBAHASAN}

\section{Laju Pertumbuhan}

Hasil pengamatan dari laju pertumbuhan harian udang selama pemeliharaan (Tabel 1), menunjukkan bahwa perlakuan ablasi memperlihatkan pengaruh yang positif $(\mathrm{P}>0,05)$. Udang yang diablasi mata bilateral lebih baik daripada yang diablasi unilateral dan tanpa ablasi dan ablasi unilateral masih lebih baik daripada pertumbuhan udang yang tanpa ablasi (kontrol).

Tabel 1. Rataan Laju Pertumbuhan harian dan bobot akhir udang galah pada perlakuan ablasi unilateral, bilateral dan kontrol selama pemeliharaan 8 minggu

Table 1. Average daily growth rate and absolute growth of unilateral and bilateral ablated and control during 8 week rearing period of giant prawn

\begin{tabular}{lcc}
\hline $\begin{array}{c}\text { Perlakuan } \\
\text { Treatment }\end{array}$ & $\begin{array}{c}\text { Laju pertumbuhan harian } \\
\text { Daily Growtb rate (\%) }\end{array}$ & $\begin{array}{c}\text { Pertumbuhan mutlak } \\
\text { Absolute growtb (g) }\end{array}$ \\
\hline Tanpa ablasi & $0,55^{\mathrm{a}}$ & $3.865^{\mathrm{a}}$ \\
(Unablated) & $(0,083)$ & $(1,065)$ \\
Ablasi unilateral & $0,820^{\mathrm{b}}$ & $6,496^{\mathrm{b}}$ \\
(Unilateral ablation) & $(0,092)$ & $(1,530)$ \\
Ablasi bilateral & $1,085^{\mathrm{c}}$ & $9,689 \mathrm{c}$ \\
(Bilateral ablation) & $(0,167)$ & $(2,303)$ \\
\hline \hline
\end{tabular}


Udang yang diablasi secara bilateral mempunyai pertumbuhan paling besar, disusul unilateral dan tanpa ablasi. Pertumbuhan mutlak yang dicapai (Tabel 2) menunjukkan bahwa pada ablasi bilateral ialah 1,5 kali lebih cepat dibanding ablasi unilateral dan 2,5 kali lebih cepat dibanding dengan tanpa ablasi. Demikian pula pertumbuhan udang pada ablasi unilateral lebih cepat 1,7 kali dibanding dengan udang yang tanpa ablasi.

Tabel 2. Pertambahan berat rata-rata udang pada ketiga perlakuan yang dipelihara selama 8 minggu

Table 2. Average weight gain of giant prawn of different treatments during 8 week rearing poeriod

\begin{tabular}{lccc}
\hline \hline \multicolumn{1}{c}{ Parameter } & $\begin{array}{c}\text { Ablasi unilateral } \\
\text { Unilateral ablation } \\
\%\end{array}$ & $\begin{array}{c}\text { Ablasi bilateral } \\
\text { Bilateral ablation } \\
\%\end{array}$ & $\begin{array}{c}\text { Tanpa ablasi } \\
\text { Unablated } \\
\%\end{array}$ \\
\hline Rata-rata (Means) & $63,53^{\mathrm{a}}$ & $91,70^{\mathrm{b}}$ & $38,97^{\mathrm{c}}$ \\
$\begin{array}{l}\text { Standar deviasi } \\
\text { (Deviation standard) }\end{array}$ & 8,45 & 16,62 & 6,59 \\
\hline \hline
\end{tabular}

Keterangan (Note): $\quad$ Tanda (buruf) yang berbeda = berbeda nyata (value with different letter sign indicates significance differents)

Hasil tersebut di atas menunjukkan bahwa udang yang diablasi baik unilateral maupun bilateral mempunyai pertumbuhan yang lebih baik dibandingkan dengan tanpa ablasi $(\mathrm{P}<0,05)$. Hal ini sesuai dengan hasil Mauviot dan Castell (1976) yang menyatakan bahwa ablasi mata dapat menyebabkan meningkatnya pertambahan berat udang pada waktu ganti kulit, karena hilangnya MIH mempengaruhi penyerapan air saat ganti kulit. Selain itu karena pada saat dilakukan ablasi, organ-X dan kelenjar sinus hilang pengaruhnya dan dengan hilangnya pengaruh tersebut kecepatan molting menjadi dua kali lipat dibanding udang normal (Sochasky et al., 1973; Nurjana, 1984).

Pada ablasi unilateral masih diproduksi hormon penghambat molting (MIH) meskipun kadarnya relatif rendah, namun mampu menghasilkan kecepatan ganti kulit yang lebih baik dibanding kontrol. Pada ablasi bilateral diduga produksi MIH dapat ditiadakan sama sekali sehingga udang dapat tumbuh jauh lebih cepat dibandingkan kontrol dan ablasi unilateral. Pertumbuhan bobot rata-rata yang dicapai dalam waktu 8 minggu pada ablasi bilateral 9,69 g, unilateral 6,5 g dan kontrol 3,86 $\mathrm{g}$ (Tabel 1). Hasil tersebut sesuai dengan pendapat Chu dan Chow (1992) bahwa ablasi mata dapat menyebabkan meningkatnya penyerapan air ke dalam sel tubuh udang, dengan demikian ablasi bilateral akan menghasilkan timbunan air dalam tubuh udang yang lebih banyak dibanding ablasi unilateral dan kontrol. 
Ablasi mata ternyata tidak hanya mempengaruhi kadar air dalam tubuh udang, akan tetapi juga memperpendek siklus ganti kulit. Dengan demikian udang akan lebih cepat tumbuh seiring kecepatan ganti kulit yang dapat dicapai. Hal tersebut sesuai dengan kondisi tubuh udang yang mempunyai kulit keras dan tidak elastis akibat proses seklerotisasi dan kalsifikasi, maka untuk pertumbuhannya memerlukan pergantian kulit (Russel-Hunter, 1979). Hasil yang diperoleh dalam penelitian ini sesuai degan pernyataan tersebut bahwa pada perlakuan ablasi terjadi 2-3 kali ganti kulit, sedangkan udang yang tidak diablasi baru 1-2 kali ganti kulit.

\section{Kelangsungan Hidup}

Derajat kelangsungan hidup juvenil udang galah selama penelitian berlangsung ternyata berhubungan dengan perlakuan. Persentase kelangsungan hidup yang diperoleh selama penelitian 8 minggu adalah $47,75 \%$ (ablasi unilateral), 26,0\% (ablasi bilateral) dan 63,0\% (kontrol), hal ini menunjukkan adanya pengaruh yang nyata antar seluruh perlakuan $(\mathrm{P}<0,05)$.

Pada ablasi bilateral dengan pemotongan kedua tangkai matanya maka keseimbangan endokrin akan terganggu karena hilangnya organ-X dan kelenjar sinus. Hal ini ternyata juga berpengaruh terhadap daya kelangsungan hidupnya di mana udang yang diablasi secara bilateral mortalitasnya paling tinggi kemudian diikuti ablasi unilateral dan kemudian tanpa ablasi.

Pengaruh dari ablasi adalah rendahnya kandungan mineral dalam kutikula udang. Kadar kalsium yang rendah menyebabkan kulit udang (eksoskeleton) menjadi lemah dan tidak tahan terhadap perubahan lingkungan, sehingga memungkinkan terjadinya kanibalisme atau kematian. Kulit yang lunak setelah ganti kulit membuat pergerakan udang tidak lincah, sehingga tidak dapat menghindar jika ada individu lain yang menyerangnya.

Kematian yang terjadi diduga sebagian besar sebagai akibat dari proses ablasi, karena hampir semua kematian terjadi segera setelah ganti kulit. Ada beberapa kemungkinan berhubungan dengan proses kematian dalam kasus ini. Pertama, kondisi tubuh udang yang lemah pada saat ganti kulit dengan mudah menjadi mangsa individu lain sehingga terjadi kematian. Ke dua, pengaruh dari ablasi adalah rendahnya kandungan mineral dalam kulit udang, sehingga eksoskeleton menjadi lemah dan tidak tahan terhadap perubahan lingkungan, sehingga terjadi kematian. Ke tiga, menurut Alava dan Lim (1983) bahwa proses ganti kulit merupakan penyebab stres yang mengakibatkan kematian pada udang. Kemungkinan ini akan menjadi lebih besar karena frekuensi molting yang tinggi sebagai akibat ablasi. Hal tersebut diperkuat oleh pengalamannya pada Crayfish (Cambarus sp.) yang kehilangan tangkai matanya mengakibatkan kematian hingga $100 \%$. 


\section{Kualitas Air}

Penyiponan atau penggantian air yang dilakukan setiap hari bertujuan untuk mempertahankan kondisi kualitas air tetap baik. Hasil monitoring kualitas air selama penelitian berlangsung terlihat pada Tabel 3.

Tabel 3. Kondisi kualitas air media selama 8 minggu masa pemelirahaan Table 3. Water quality of juvenil rearing media for 8 week rearing period

\begin{tabular}{llccc}
\hline \multicolumn{2}{c}{$\begin{array}{c}\text { Parameter } \\
\text { n }\end{array}$} & $\begin{array}{c}\text { Tanpa ablasi } \\
\text { Unablated }\end{array}$ & $\begin{array}{c}\text { Ablasi unilateral } \\
\text { Unilateral ablation }\end{array}$ & $\begin{array}{c}\text { Ablasi bilateral } \\
\text { Bilateral ablation }\end{array}$ \\
\hline Suhu (Temp.) & ${ }^{\circ} \mathrm{C}$ & & & \\
- pagi (morning) & $26,0-26,5$ & $26,0-26,5$ & $26,0-26,5$ \\
- sore (afternoon) & $27,0-28,0$ & $27,0-28,0$ & $27,0-28,0$ \\
pH & & $6,5-7,0$ & $6,5-7,0$ & $6,5-7,0$ \\
DO & ppm & $4,37-8,40$ & $4,85-7,53$ & $4,33-7,95$ \\
$\mathrm{NO}_{2}$ & ppm & $0,09-0,73$ & $0,03-2,20$ & $0,04-2,20$ \\
$\mathrm{NH}_{4}$ & ppm & $0,17-0,64$ & $0,11-0,80$ & $0,09-0,57$ \\
\hline \hline
\end{tabular}

Suhu air media (New dan Singholka, 1982), nilai pH (Suprayitno, 1986) dan oksigen terlarut (New dan Singholka, 1982; Suharto et al., 1992) secara keseluruhan masih mendukung pertumbuhan udang galah.

Kandungan nitrit yang didapat seperti pada Tabel 3 diduga ikut ambil bagian terhadap tingginya angka kematian ataupun lambatnya pertumbuhan. Menurut Amstrong et al. (1978) kadar nitrit 1,8 ppm sudah mampu menghambat pertumbuhan sebesar $35 \%$ pada udang galah. Sedangkan pada udang putih (Penaeus indicus) pengaruhnya menghambat sebesar $50 \%$ pada konsentrasi 6,4 ppm (Cholik, 1988). Hal tersebut lebih mungkin lagi pada konsentrasi oksigen rendah, karena mekanisme toksisitasnya berhubungan dengan transpor oksigen dalam darah (Poernomo et al., 1988).

Kadar amonia yang didapat selama penelitian (Tabel 3) diduga juga sebagai penyebab terjadinya kematian udang, mengingat pendapat Tsai (1989) bahwa batas aman amonia pada udang adalah 0,1 ppm. Kadar amonia mulai berpengaruh terhadap pertumbuhan sebesar $50 \%$ adalah pada kadar $0,45 \mathrm{ppm}$, sedangkan pada kadar 1,29 ppm menyebabkan kematian.

\section{KESIMPULAN DAN SARAN}

1. Ablasi mata unilateral dan bilateral pada juvenil udang galah menyebabkan peningkatan laju pertumbuhan 1,7 hingga 2,5 kali dibanding udang tanpa ablasi (kontrol). Mortalitas juvenil udang galah yang diablasi unilateral mencapai $59,3 \%$, ablasi bilateral $74 \%$ dan pada kontrol $37 \%$. 
2. Ablasi mata menyebabkan penurunan derajat kelangsungan hidup.

\section{DAFTAR PUSTAKA}

Alava, V.R. \& C.Lim, 1983. The quantitative dietary protein requirements of Penaeus monodon juvenile in controlled environment. Aquaculture 30: 53-61.

Amstrong, D.A., D.Chippendale, A.W.Knight \& J.Colt, 1978. Interaction of ionized and unionized ammonia on short term survival and growth of prawn larvae. M.rosenbergii. Biol. Bull. 154:15-31.

Budiono, R.S., W.Tjahjaningsih, R. Kusdarwati, M. Arief \& E. Sunarwati, 1990. Pemberian beberapa macam produk makanan udang yang beredar di pasaran terhadap pertumbuhan udang windu (Penaeus monodon) dalam industri glondongan (juvenil), Lembaga Penelitian Universitas Airlangga, Surabaya pp. 90.

Cholik, F., 1988. Pengolahan mutu air tambak udang. Seminar Aquabisnis udang. Tanggal 19-20 September 1988. Dumai, Riau: 1-45.

Chu, K.H. \& W.K.Chow, 1992. Effect of unilateral versus bilateral eyestalk ablation on moulting and growth of the shrimp, Penaeus chinensis (osbeck, 1765) (Decapoda, Penaeidae). Crustaceana 62 (3):225-233p. J. Brill. Leiden, Amsterdam.

Gad, S.C. \& C.S.Weil, 1982. Statistics for toxicologists. Dalam Hayes,A.W., (Ed) 1982. Principle and methods of toxicology. Raven Press, New York: 273-320 p.

Mauviot, J.C \& J.D.Castell, 1976. Moult-and growth enhancing effects of bilateral eyestalk ablation on juvenile and adult American lobsters (Humarus americanus). J. Fish. Res. Board. Can. 33:1922-1929.

Menasveta, P. \& S.Piyatiratitivokul, 1982. Effects of different culture system on growth, survival and production of giant freshwater prawn $(M$. rosenbergii de Man) dalam New, M.B. 1982. Giant prawn farming. Elsevier scientific publishing company, Amsterdam: 175-189p

Mulyani, S., 1986. Pengaruh kombinasi perlakuan antara umur dan ablasi mata terhadap pertumbuhan udang galah (M.rosenbergii de Man). Thesis sarjana S1 Fakults Biologi Universitas Jenderal Sudirman, Purwokerto: 90p.

New, M.B. \& S.Singholka, 1982. Freshwater Prawn Farming; A mannual for the culture of M.rosenbergii. F.A.O. Fish. Tec. Pap. 225: 116p. IFS. Bangkok

Nurjana, M.L., 1979. Produksi massal induk matang telur udang Penaeid melalui ablasi mata. Bull. Warta Mina 3(6): 24- 27.

Nurjana, M.L., 1984. Merangsang kehamilan udang melalui teknik ablasi mata. Bull. Warta Mina 3(6) : 24-27. 
Poernomo, A., 1985. Persyaratan pakan untuk budidaya pantai. Pros. Rapat Kerja Teknis Tepung Ikan. Pusat Penelitian dan Pengembangan Perikanan, Jakarta : 91-97.

Poernomo, A. \& M.Yunus, 1980. Pematangan induk udang windu dengan ablasi mata dan pemeliharaan larvanya. Bull.Pen. Perikanan. 1:76-86. Pusat Penelitian dan Pengembangan Perikanan, Jakarta.

Poernomo, A., S.Sunarno \& S.Dahlan, (ed) 1988. Pembuatan tambak udang di Indonesia Balai Penelitian Perikanan Budidaya Pantai, Maros : 30p.

Russel-Hunter, W.D., 1979. A Life of Invertebrates. Mc Milan Publishing Co., Inc. New York pp 650.

Steel, R.G.D \& J.H.Torrie, 1981. Prinsip dan prosedur statistika: Suatu pendekatan biometrik. Ed. ke-2. Terj. dari Principles and procedures of statistics, oleh Sumantri, B. PT. Gramedia, Jakarta xxiii +748 hal.

Sochasky, J.B., D.E.Aken \& D.W.McLeese, 1973. Does eyestalk ablation accelerate molting in the lobster Humarus americanus. J.Fish.Res. Board. Canada. 30:1600-1603.

Suharto, H.H., Jaelani, M.F.Sukadi, 1992. Pengembangan pembenihan udang galah (Macrobrachium rosenbergii) sistem resirkulasi skala rumah tangga di wilayah sawah tambak. Bull. Penel. Perik. Darat. 11(2): 20-30.

Suprayitno, S.H., D. Widigdo \& Maskur, 1986. Petunjuk budidaya udang galah (Macrobrachium rosenbergii de Man). Direktorat Jenderal Perikanan, Balai Budidaya Air Tawar, Sukabumi: 23 hal.

Tsai, C.K., 1989. Water quality management, Akiyama, D.M. (Ed) Proceeding of the Southeast Asia Shrimp Farm Management Work Shop, Philippines, Indonesia, Thailand, July 26 - August 11, 1989 :56-74. 